\title{
Lectotypification of thirteen names in Dioscoreaceae R.Br.
}

\author{
Akramul Hoque, Pakshirajan Lakshminarasimhan ${ }^{1}$ and Debabrata Maity ${ }^{2}$ \\ Taxonomy and Biosystematics Laboratory, Department of Botany, University of Calcutta, 35 Ballygunge \\ Circular Road, Kolkata 700019, West Bengal, India \\ ${ }^{1}$ Botanical Survey of India, Western Regional Centre, 7 Koregaon Road, Pune 411001, Maharashtra, India \\ ${ }^{2}$ Author for correspondence, e-mail:debmaity@yahoo.com
}

[Received 12.11.2018; Revised 19.12.2018; Accepted 24.12.2018; Published 31.12.2018]

\begin{abstract}
Thirteen names in the genus Dioscorea L., viz., D. arachidna Prain \& Burkill; D. bulbifera L. var. kacheo Prain \& Burkill; D. bulbifera L. var. simbha Prain \& Burkill; D. bulbifera L. var. suavior Prain \& Burkill; D. bulbifera L. var. vera Prain \& Burkill; D. collinsae Prain \& Burkill; D. pentaphylla L.var. cardonii Prain \& Burkill; D. pentaphylla L.var. hortorum Prain \& Burkill; D. pentaphylla L. var. kussok Prain \& Burkill; D. pentaphylla L. var. simplicifolia Prain \& Burkill; D. pentaphylla L. var. suli Prain \& Burkill; D. scortechinii Prain \& Burkill and D. wattii Prain \& Burkill are lectotypified here as part of the revisionary study of the family Dioscoreaceae R.Br. in India.
\end{abstract}

Key words: Dioscorea, Lectotype, Isolectotype, Syntype

\section{INTRODUCTION}

The genus Dioscorea L. (Dioscoreaceae) comprises about 630 species and widely distributed in tropical and subtropical regions of both the worlds (Mabberley 2017). In India, the genus is represented by 33 species and 24 varieties and a majority of the members are distributed in the Himalayan regions (Karthikeyan et al. 1989). During the revisionary study of the family Dioscoreaceae in India Hoque (2002) has already published a detailed account on the original materials of the genus Dioscorea deposited at different herbaria. Few Names of the genus has already been typified by different workers (Merrill 1917; Milne-Redhead 1975; Howard 1979; Nicolson et al. 1988; Jayasuriya 1995; Forman 1997; Wilkin 2001; Wilkin et al. 2007; Pagare et al. 2015a,b; Pagare \& Arisdason 2016a,b,). As a part of this revisionary study of Dioscoreaceae in India thirteen names have been lectotypified here in accordance in the provisions of ICN (Turland et al. 2018). For all thirteen names details on syntypes of and explanatory note are provided.

\section{MATERIALS AND METHODS}

The original materials of all thirteen names of Dioscorea housed in different Indian herbaria were consulted carefully. The protologues of all names are critically studied to ascertain proper typification, and the high resolution digital images of herbarium specimens deposited at $\mathrm{K}, \mathrm{E}, \mathrm{BM}, \mathrm{B}, \mathrm{GH}, \mathrm{G}$ and $\mathrm{P}$ were also examined online.

\section{TYPIFICATION}

Dioscorea arachidna Prain \& Burkill, J. Proc. Asiat. Soc. Bengal 10: 21. 1914. 
Lectotype (designated here): India, Assam, Nowgong, Lungfer near Lumding, 21 Sept. 1911, Herb. R.E.P., Kalkaprasad 35581, CAL0000003983!; Isolectotype: K000098163, image!.

Remaining syntype: India, Assam, Nowgong, Lungfer near Lumding, Herb. R.E.P., Burkill s.n. (CAL!).

Note: While describing Dioscorea arachidna, the original authors cited two gatherings from same locality, viz., I.H. Burkill s.n. and Kalkaprasad 35581 (CAL0000003983) and 35583 (K001142327). The specimens were collected from the Nowgong (presently Nagaon) district of Assam. After critical search, three specimens have been traced, one at $\mathrm{K}$ (Kalkaprasad 35581, K000098163) and two at CAL (Kalkaprasad 35581, CAL0000003983 and Burkill s.n.). Another specimen from the same locality with same date of collection and collector has also been traced at K (Kalkaprasad 35583, K001142327). However, authors specifically mentioned only Kalkaprasad 35581 in the protologue. So, Kalkaprasad 35583 is not considered here as the original material. Among the two original materials, the specimen at CAL with four tubers, which is one of the diagnostic characters of the species and therefore, this specimen is selected and designated here as lectotype of Dioscorea arachidna Prain \& Burkill and its duplicate at $\mathrm{K}(\mathrm{K} 000098163)$ is considered as isolectotype.

Dioscorea bulbifera L. var. kacheo Prain \& Burkill, J. Proc. Asiat. Soc. Bengal 10: 26. 1914.

Lectotype (designated here): India, West Bengal, Darjeeling, Tista Valley, 11.8.1912, Gage 34228 (CAL0000026162!).

Remaining syntypes: No syntype has found.

Note: Dioscorea bulbifera L. var. kacheo was described by Prain \& Burkill (1914). In the protologue, authors did not cite any specimen, however, they had provided details of the place of occurrence as "montibus sikkimensibus et in locis ab iis versus orientem tendentidus reperiuntur". But after thorough survey during this revisionary work, only a single specimen at CAL, viz., Gage 34228 (CAL0000026162) has been traced with plant name written by the original author on the herbarium sheet. Moreover, this species was collected from the same locality as mentioned by the authors. Thus it is considered as original material. However, from the publication (Prain and Burkill, 1914) it is clear that the plant was common in that locality and multiple specimens are associated with name. Therefore, Dioscorea bulbifera L. var. kacheo is lectotypified here with Gage 34228 (CAL0000026162).

Dioscorea bulbifera L. var. simbha Prain \& Burkill, J. Proc. Asiat. Soc. Bengal 10: 26. 1914.

Lectotype (designated here): India, West Bengal, Darjeeling, Mungpu, $2800 \mathrm{ft}$ (about $850 \mathrm{~m}), 31.7 .1903$, A.C. Hartless 1, acc. no. 475530 CAL!

Remaining syntypes: Meghalaya, Cherrapunjee, 11.8.1912, R.K. Das 35633 (CAL0000026164).

Sikkim Himalaya, Pashok, Oct. 1903, J.L. Lister s.n., acc. no. 475525 CAL!; West Bengal, Eastern Himalaya, Sureil, $5000 \mathrm{ft}$ (about $1500 \mathrm{~m}$ ), 21.9.1912, P.T. Russell 27, CAL!; Mungpoo, $2500 \mathrm{ft}$ (about $750 \mathrm{~m}$ ), 21.8.1912, P.T. Russell 21, CAL!

Note: Within the protologue of D. bulbifera var. simbha, the authors Prain and Burkill provided distribution localities of this taxon, but did not mention any type collection. In our search for potential uncited Type material (see Shenzhen Code Art. 9.1 Note 1), we located 
Akramul Haque et al. 301
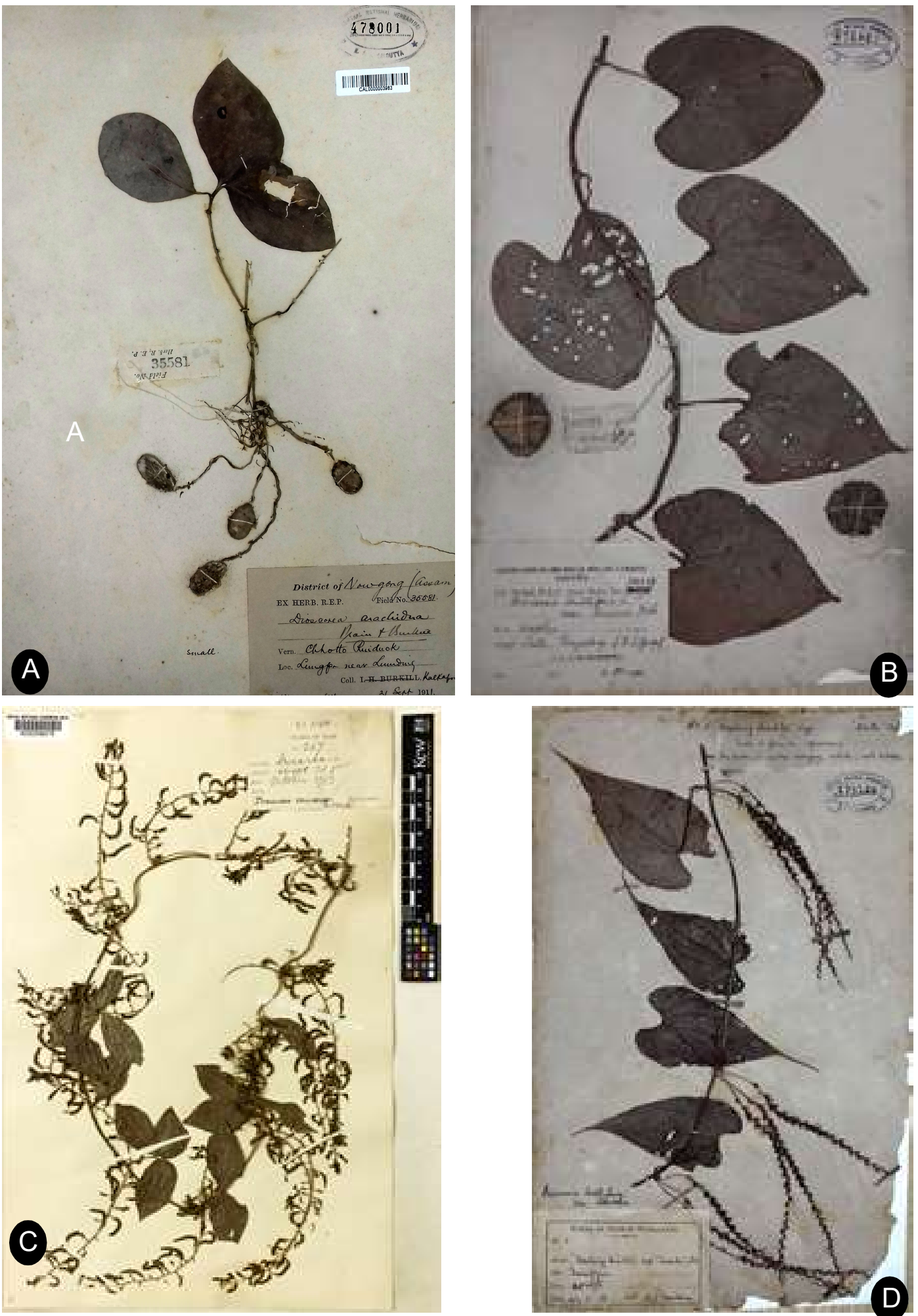

PLATE - I. Lectotypes of: A. Dioscorea arachidna; B. D. bulbifera var. suavior; C. D. collinsae; D.D. bulbifer var. simbha [@: Director, BSI (A, B \& C); RBG, Kew (D)] 
five collections, viz., A.C. Hartless 1; J.L. Lister s.n.; R.K. Das 35633; P.T. Russell 21; and P.T. Russell 27, and these are housed at CAL. All the five collections were made before 1914 from the localities cited in the protologue, and the specimen sheets were annotated by the authors. Therefore, these specimens are most likely the original materials used by Prain and Burkill for the description of their varietal taxon. Among these specimens, $A$.C. Hartless 1 is the best-preserved specimen with leaves and male inflorescence bearing mature male flowers. Since these features are critical to distinguish var. simbha from other related taxa, we herewith choose this specimen to lectotype the name $D$. bulbifera var. simbha.

Dioscorea bulbifera L. var. suavior Prain \& Burkill, J. Proc. Asiat. Soc. Bengal 10(1): 26. 1914.

Lectotype (designated here): West Bengal, Darjeeling, Tista, 4 Oct. 1912, A.T. Gage 38773, acc. no. 476862 CAL!,

Remaining syntypes: Madhya Pradesh, Bhopal, Narashingarh, 18.7.1904, Herb. R.E.P. Kalkapershad Tewari s.n., acc. no. 477020 CAL!; Maharashtra, Thana, Kalyan, 22 Sept. 1910, D. Hooper 34638, acc. no. 476944 CAL!.

Note: In the protologue authors did not mention any specimen. However, during the presen study three herbarium specimens from three gatherings, viz., A.T. Gage 38773 (CAL, acc. no. 476862); Kalkapershad Tewari s.n. (CAL, acc. no. 477020) and D. Hooper 34638 (CAL, Acc. No. 476944) where the varietal name had been written by the authors on herbarium sheets have been traced. Therefore, all these specimens are here considered as original materials. Among these specimens A.T. Gage 38773 (CAL, acc. no. 476862) is with vegetative twig and bulbils of diagnostic importance. Thus this specimen is selected and designated here as lectotype of Dioscorea bulbifera L. var. suavior Prain \& Burkill.

Dioscorea bulbifera L. var. vera Prain \& Burkill, J. Proc. Asiat. Soc. Bengal 10(1): 26. 1914.

Lectotype (designated here): Eastern Himalaya, Mungpoo, $2000 \mathrm{ft}$ (about $600 \mathrm{~m}$ ), 31.8.1912, P.T. Russell 23, acc. no. 475558 (CAL0000026163!).

Remaining syntypes: Eastern Himalaya, Sitong, 3000ft (about 900 m), 26.3.1912, P.T. Russell 11, acc. no. 475561CAL!

Note: During publication of this taxon authors did not provide any specimen details. However, along with the diagnosis of the taxon they had mentioned the place of occurrence as "ubique vulgaris", means everywhere common. After thorough study, we have found two specimens from two gatherings, viz., P.T. Russell 23 (CAL0000026163) and P.T. Russell 11 (CAL, acc. no. 475561) with author's handwritings (varietal epithet) on herbarium sheets, which were collected before publication of the name and exhibit similar characters as mentioned in the protologue, therefore, these specimens are considered here as original materials. Among these two specimens, P.T. Russell 23 (CAL0000026163) is with a twig having well-preserved leaves, bulbils and male inflorescence with mature male flowers of diagnostic importance. Thus this specimen is selected and designated here as lectotype of Dioscorea bulbifera L. var. vera Prain \& Burkill.

Dioscorea collinsae Prain \& Burkill, Bull. Misc. Inform. Kew 1927: 234. 1927.

Lectotype (designated here): SIAM, Sriracha, about 20 feet (about 6 m), October, 1913, Mrs. D.J. Collins 267, K (K000098276, image!); Isolectotype: K001143751, image!). 
Notes: Within the protologue, the authors Prain and Burkill cited three gatherings, viz., 1) Mrs. D.J. Collins 267; 2) Mrs. D.J. Collins 268; and 3) Bradley s.n. (lacking locality). Of the three collections, the authors distinguished Collins 267 as the type. Consequently, the remaining two collections constitute paratypes (see Shenzhen Code Art. 9.7, Note 5). Although Prain and Burkill used the term type, they did not use the term holotype or indicate where it is housed. In our study, we located two specimens of Collins 267 housed at Kew and neither of these specimens is annotated as the Holotype by the authors. Therefore, both specimens, albeit from a single gathering, constitute syntypes (Art. 40.2 Note 1). We also located one specimen of Collins 268 at K (barcode: K000098275). We also tried to locate the other paratype (Bradley s.n.) and checked several herbaria (e.g., B, BM, CAL, E, G, $\mathrm{GH}, \mathrm{K}$, and $\mathrm{P}$ ), but have not been successful in locating any specimen. Regarding the typification of the name of $D$. collinsae, of the two specimens of Collins 267 housed at K, one specimen (barcode K000098276) has been preserved well depicting necessary diagnostic characters, and it is designated here as the lectotype. Its duplicate (barcode: K001143751) is treated here as the isolectotype.

Dioscorea pentaphylla L. var. cardonii Prain \& Burkill, J. Proc. Asiat. Soc. Bengal 10: 23. 1914.

Lectotype (designated here): Gorakhpur, Ramgarh, 31 Oct. 1910, Kalka Prasad 34807, acc. no. 474298 CAL!

Remaining syntypes: Balrampur, 9.3.1900, Herb. Hort. Bot. Cal., Burkill \& Prain s.n., acc. no. 474110 CAL! (CAL0000026165); Gorakhpur, Ramgarh, 31 Oct. 1910, Kalka Prasad 34804, acc. no. 474297 CAL!; Gidung, Monharpur, 4.11.1903, Herb. R.E.P., Kalka Prashad 19707, two sheets, acc. nos. 474292, 474293 CAL!; Rengarita and Biru, Sept. 1904, Herb. Hort. Bot. Cal., Father Cardoni 1, acc. no. 473958 CAL! \& 4, two sheets, acc. nos. 474295, 474294 CAL!; Central Province, Melghat Division, Divisional Forest Officer, 15.12.1910, Herb. R.E.P. Reg. No. 33458, three sheets, acc. nos. 478013, 478014, 478015 CAL!

Note: In the protologue, though the authors did not mention any specimen, provided the place of occurrence. After thorough search and critical study, eleven specimens from seven gatherings, viz. Kalka Prasad 34807, acc. no. 474298 CAL!); Burkill \& Prain s.n. (CAL0000026165); Kalka Prasad 34804, acc. no. 474297 CAL!; Kalka Prashad 19707, acc. nos. 474292, 474293 CAL!); Father Cardoni 4, acc. nos. 474295, 474294 CAL!; Herb. R.E.P. Reg. no. 33458, acc. nos. 478013, 478014, 478015 CAL!, where author himself had written the varietal name on the herbarium sheets. Moreover, all these specimens were collected from same locality well before publication of the name. Therefore, all these specimens are considered here as original materials. The specimen Kalka Prasad 34807, acc. no. 474298 CAL! is a female plant with flowers and immature fruits of diagnostic importance. Thus Dioscorea pentaphylla L. var. cardonii Prain \& Burkill is here lectotypified with Kalka Prasad 34807, acc. no. 474298 CAL!

Dioscorea pentaphylla L. var. kussok Prain \& Burkill, J. Proc. Asiat. Soc. Bengal 10: 23. 1914.

Lectotype (designated here): Eastern Himalaya, Mungpoo, 2000ft (about $600 \mathrm{~m}$ ), 9.9.(19)12, P.T. Russell 24, acc. no. 474301 (CAL0000026168!).

Remaining syntypes: Eastern Himalaya, Mungpoo, $2500 \mathrm{ft}$ (about $750 \mathrm{~m}$ ), 29.5.1912, P.T. Russell 22, acc. no. 474299 CAL!; Eastern Himalaya, Mungpoo, $3000 \mathrm{ft}$ (bout $900 \mathrm{~m}$ ), 15.4.1912, P.T. Russell 14, acc. no. 474300 CAL!. 
304 Lectotypification of names in Dioscoreaceae
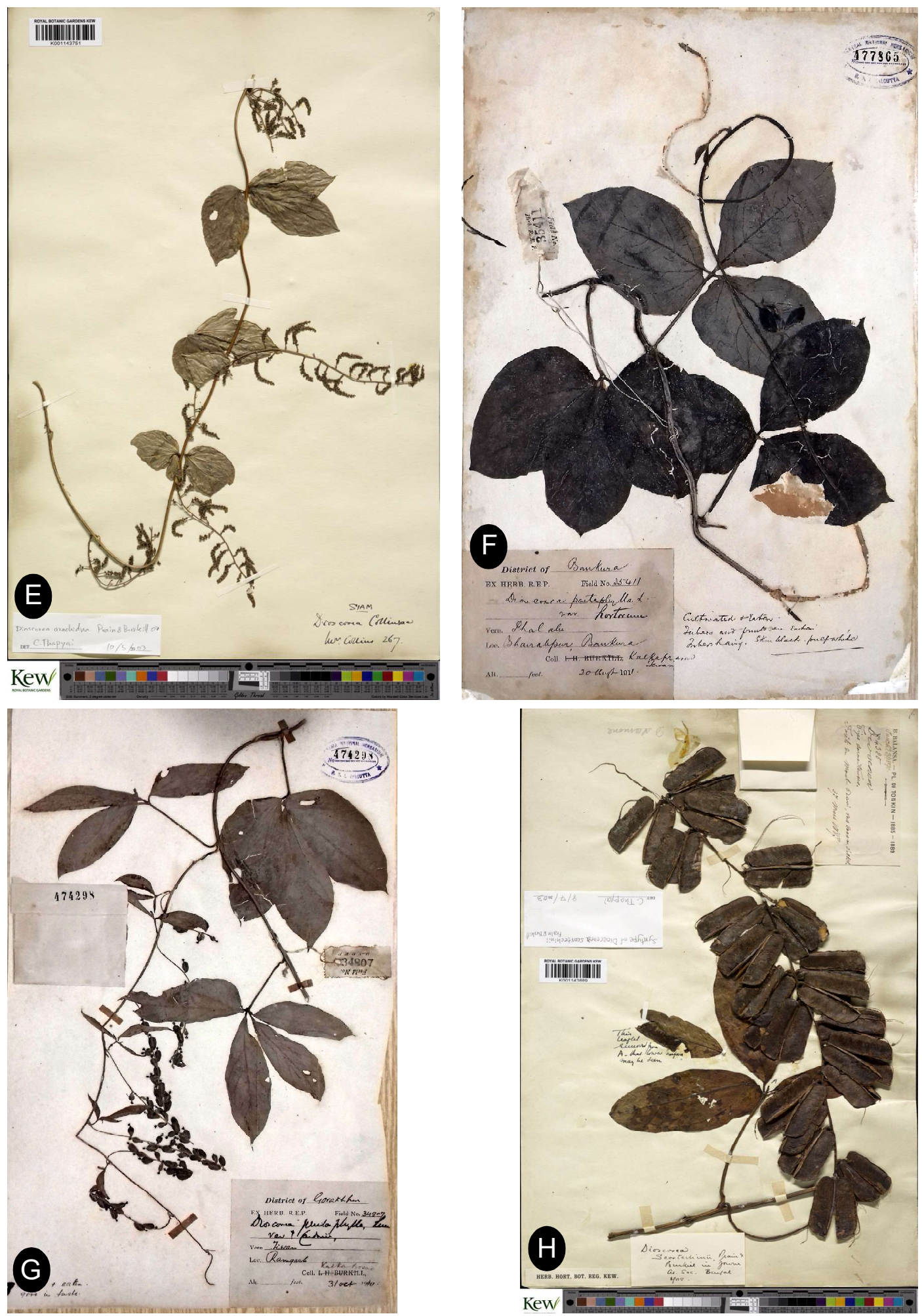

PLATE - II. E. D. collinsae; F. D. pentaphylla var. hortorum; G. D. pentaphylla var. cardonii; H. scortechinii [@: RBG, Kew (E \& H); Director, BSI (F \& G)] 
Note: Authors did not mention any specimen in the protologue of the name. However, only a few diagnostic characters and its place of occurrence (mainly in Sikkim) had been mentioned in the protologue. During critical search of the original materials, three authentic specimens, viz., P.T. Russell 24 (CAL0000026168); P.T. Russell 22, acc. no. 474299 CAL and P.T. Russell 14, acc. no. $474300 \mathrm{CAL}$ have been traced where the varietal name had been written on the herbarium sheets by the authors. All these specimens were collected from same locality as mentioned by Prain \& Burkill (1914) before publication of the name. Thus these materials are treated here as original materials. Among these three authentic specimens, P.T. Russell 24 (CAL0000026168) is the best preserved specimen having glabrescent leaves. Therefore, P.T. Russell 24 (CAL0000026168) is selected here as lectotype of D. pentaphylla L. var. kussok Prain \& Burkill.

Dioscorea pentaphylla L. var. hortorum Prain \& Burkill, J. Proc. Asiat. Soc. Bengal 10: 23. 1914.

Lectotype (designated here): West Bengal, Bankura, Bhairabpur, 20 Aug. 1911, Kalkaprasad Tewari 35411, CAL!, acc. no. 477865.

Remaining syntypes: West Bengal, Bankura, Bhairabpur, Aug. 1911, R.K. Das 35411, acc. no. 477863 CAL! (CAL0000026170); Bankura, Bhairabpur, 20 Aug. 1911, R.K. Das 35411, acc. no. 477864 CAL! (CAL0000026167).

Note: Authors did not provide any specimen detail in the protologue but mentioned only the diagnostic characters of the variety such as nature of tubers and leaves. During the search of original material(s) of the name three specimens, viz., Kalkaprasad Tewari 35411, acc. no. 477865 CAL!; R.K. Das 35411, acc. no. 477863 (CAL0000026170); R.K. Das 35411, acc. no. 477864, (CAL0000026167) were located at CAL, where authors written the varietal name on herbarium sheets. These materials were collected much before publication of the taxon, and also well-matched with the protologue. Therefore, these specimens are considered here as original materials. Among these specimens Kalkaprasad Tewari 35411, acc. no. 477865 CAL! is the best preserved one with healthy trifoliolate leaves and stem and thus selected as the lectotype of Dioscorea pentaphylla L. var. hortorum Prain \& Burkill.

Dioscorea pentaphylla L. var. simplicifolia Prain \& Burkill, J. Proc. Asiat. Soc. Bengal 10: 23.1914.

Lectotype (designated here): Central Provinces, Melghat, 15 Dec. 1910, Herb. R.E.P. Reg. No. 33458, acc. no. 477862 CAL! (CAL0000026166, specimen on left); Isolectotypes: Herb. R.E.P. Reg. No. 33458, acc. no. 477862 CAL! (specimens at middle and on right).

Remaining syntypes: Kerala, Melghat, 6.8.1912, Herb. Hort. Cal. Reg. No. 33459, CAL!

Note: In the protologue, authors had relied on the features of leaves and flowers to establish this taxon. But they did not cite any specimen except place of collection of the taxon, i.e., mountains of Melghat. During the present revisionary study two herbarium sheets, viz., Herb. R.E.P. Reg. No. 33458 and Herb. Hort. Cal. Reg. No. 33459 (CAL) collected from same locality as mentioned in the protologue but with different dates of collections have been traced at CAL. Authors had written the varietal name on these herbarium sheets and the character of the specimens matched with the protologue. Therefore, these specimens are treated here as original materials. Among the original specimens, a part of Herb. R.E.P. Reg. No. 33458 (CAL0000026166, specimen on left) has been designated as lectotype. The selected specimen has preference over the other syntype materials on account of better 
preservation, presence of entire leaves of diagnostic importance, and its duplicate specimens (Herb. R.E.P. Reg. No. 33458, acc. no. 477862 CAL, specimens at middle and on right) would be considered as isolectotype.

Dioscorea pentaphylla L. var. suli Prain \& Burkill, J. Proc. Asiat. Soc. Bengal 10: 23. 1914.

Lectotype (designated here): Sikkim Himalaya, Kupok, Terai, Aug. 1848-9, J.D. Hooker s.n. (K000098195, specimen on right, image!); Isolectotype: K000098195 (specimen on left, image!).

Remaining syntypes: Sikkim Himalaya, Kupok, Terai, Aug. 1848-9, J.D. Hooker s.n. (K000098194, image!); Eastern Himalaya, Sitong, 3000 ft (about 900 m), 25.3.1912, P.T. Russell 10, acc. no. 474288 CAL!; Eastern Himalaya, Mungpoo, 1.4.1912, P.T. Russell 18, acc. no. 474289 CAL!; Eastern Himalaya, Mungpoo, $2000 \mathrm{ft}$ (about 600 m), 9.9.1912 , P.T. Russell 25, acc. no. 474287 CAL!.

Note: In the protologue the authors did not cite any specimen. They had only mentioned Himalaya as place of collection of this variety. During course of this study, five specimens of four gatherings, viz., J.D. Hooker s.n. (K000098194, K000098195); P.T. Russell 10, acc. no. 474288 CAL); P.T. Russell 18, acc. no. 474289 CAL) and P.T. Russell 25, acc. no. 474287 CAL). These specimens were collected from Sikkim Himalaya and the varietal name had been written on the herbarium sheets by the authors. Thus all these materials are considered here as original specimens. Among the original specimens, part of J.D. Hooker s.n. (K000098195, specimen on right) has been designated as lectotype. The selected specimen has preference over other syntypes on account of better preservation, presence of fully expanded leaves and entire male inflorescence of diagnostic importance, and its duplicate (K000098195, specimen on left) is considered as isolectotype.

Dioscorea scortechinii Prain \& Burkill, J. Proc. Asiat. Soc. Bengal 4: 455. 1908.

Lectotype (designated here): Tonkin, Monte Bavi, 6500 ped (about $2000 \mathrm{~m}$ ), 27 Mar. 1887, B. Balansa 4325 (K001143889, image!).

Remaining syntype: Perak, Maxwell's Hill, May, 1884, Scortechini s.n. (K000098262, K000098263, images!).

Note: In the protologue, authors had mentioned two gatherings, viz., Scortechini s.n. from Perak and Balansa 4325 from Tonkin. During the study, three specimens, viz., Balansa 4325 (K001143889); Scortechini s.n. (K000098262), and Scortechini s.n. (K000098263) were located at K. Among these specimens Balansa 4325 is selected here as the lectotype of Dioscorea scortechinii Prain \& Burkill, as it is in a better preserved condition with diagnostic characters.

Dioscorea wattii Prain \& Burkill, J. Proc. Asiat. Soc. Bengal 4: 457. 1908.

Lectotype (designated here): Khasia, Mambo, 3000 ped (abot 900 m), 12.5.1886, C.B. Clarke 43801 (K000098206, image!).

Remaining syntypes: Naga Hills, 3.12.(18)86, Griffith 5551 pro parte (b) (K000950637, image!); East Bengal, Griffith 5551(a)(K000098205, image!); Cherrapunji, Borpani, 1.11.1850, J.D. Hooker and T. Thomson s.n. (K000098207, image!); Sibsagar and Rajahbari, 13.4.1895, G. Watt 11264 (E00317895, image!); Bengalia orientali, s. loc., Griffith 5537 (CAL!, B100296763, image!); Dimapur, 400 ped (about 120 m), King's Collector s.n., BSIS!; Montibus Sikkimensibus ad Rishop Jhora, King s.n., CAL! 
Note: In the protologue authors cited nine gatherings, viz., C.B. Clarke 43801; Griffith 5551 pro parte (b); Griffith 5551(a); J.D. Hooker and T. Thomson s.n.; G. Watt 11264; Griffith 5537; King's Collector s.n.; King s.n. and Griffith s.n. However, during the study nine herbarium specimens from eight gatherings [viz., C.B. Clarke 43801 (K000098206); Griffith 5551 pro parte (b) (K000950637); Griffith 5551 (a) (K000098205, image!); J.D. Hooker and T. Thomson s.n. (K000098207, image!); G. Watt 11264 (E00317895); Griffith 5537 (CAL!, B100296763, image!); King's Collector s.n. (BSIS); King s.n. (CAL)] were traced. Griffith s.n. could not be located in any of the herbaria, including K, E, BM, B, GH, G, P, CAL, BSIS, etc. Among the traced specimens C.B. Clarke 43801 (K000098206) with male mature inflorescences is selected here as lectotype of $D$. wattii Prain \& Burkill.

\section{Acknowledgements}

Author are thankful to the Director, Botanical Survey of India and the Head of Office, Central National Herbarium, Botanical Survey of India, Howrah, for giving necessary permission to consult herbarium and library. We are grateful to Dr. K.N. Gandhi (GH) for his generous help. Dr. W. Arisdason (CAL) is warmly thanked for his comments on the manuscript.

\section{LITERATURE CITED}

Forman, L.L. 1997. Notes concerning the typification of names of William Roxburgh's Species of Phanerogams. Kew Bull. 52(3): 513 - 534.

Hoque, A. 2002. Types of Dioscoreaceae deposited in Indian Herbaria. J. Econ. Taxon. Bot. 26(2): $449-454$.

Howard, R. 1979. Flora of the Lesser Antilles. 1974-1989 (FL Ant) 3: 506.

Jayasuriya A.H.M. 1995. Dioscoreaceae. In: Dassanayake, M.D. (ed.), A Revised Handbook to The Flora of Ceylon 9: 47 - 80. Amerind Publishing Co. Pvt. Ltd., New Delhi.

Karthikeyan, S.; Jain, S.K.; Nayar, M.P. \& Sanjappa, M. 1989. Florae Indicae Enumeratio: Monocotyledonae. Botanical Survey of India, Calcutta.

Mabberley, D. J., 2017. Mabberley's Plant-book, A Portable Dictionary of Plants, their Classification and Uses. $4^{\text {th }}$ Edition. Cambridge University Press, Cambridge.

Merrill, E.D. 1917. Dioscoreaceae. (An) Interpretation of Rumphius, Herbarium Amboenensis. Bureau of Printing Manila. pp. 145 - 149.

Milne-Redhead, 1975. Dioscoreaceae. In: Polhill, (ed.), Flora of Tropical East Africa. Crown Agents for Overseas Govts. \& Admins., London. Pp. $1-25$.

Nicolson, D.; Suresh, C.R. \& Manilal, K.S. 1988. An Interpretation of Van Rheede's Hortus Malabaricus. Koeltz Scientific Books, Konigstein. Pp. 289 - 293.

Pagare, R.S. \& Arisdason, W. 2016a. Lectotypification of Dioscorea listeri Prain \& Burkill (Dioscoreaceae) from India. Ann. Bot. Fennici 53: $67-68$.

Pagare, R.S. \& Arisdason, W. 2016b. Lectotypification in the genus Dioscorea L. (Dioscoreaceae). Webbia 71(1): $73-81$.

Pagare, R.S.; Arisdason, W.; Krishnan, S. \& Janarthanam, M.K. 2015a. Lectotypification of two varietal names in Dioscorea glabra (Dioscoreaceae). Telopea 18: 243 246. 
Pagare, R.S.; Arisdason, W.; Krishnan, S. \& Janarthanam, M.K. 2015b. Lectotypification of Dioscorea vexans (Dioscoreaceae), an endemic and rare species from Andaman and Nicobar Islands, India. Phytotaxa 233(3): 298 - 300.

Prain, D. \& Burkill, I.H. 1908. Dioscorearum novarum Descriptiones quaedam. J. Proc. Asiat. Soc. Bengal 4(9): 447 - 457.

Prain, D. \& Burkill, I.H. 1914. A synopsis of the Dioscoreas of the Old World, Africa excluded, with descriptions of new species and varieties. J. Proc. Asiat. Soc. Bengal 10(1): $5-41$.

Prain, D. \& Burkill, I.H. 1927. The Genus Dioscorea in Siam. Bull. Misc. Inform. No. 6: $225-247$

Turland, N.J., Wiersema, J.H., Barrie, F.R., Greuter, W., Hawksworth, D.L., Herendeen, P.S., Knapp, S., Kusber, W.-H., Li, D.-Z., Marhold, K., May, T.W., McNeill, J., Monro, A.M., Prado, J., Price, M.J. \& G.F. Smith (Eds.) 2018: International Code of Nomenclature for algae, fungi, and plants (Shenzhen Code) adopted by the Nineteenth International Botanical Congress Shenzhen, China, July 2017. Regnum Vegetabile 159. Koelz Botanical Books, Glashütten. DOI https://doi.org/10.12705/Code. 2018.

Wilkin, P. 2001. Dioscoreaceae of South-Central Africa. Kew Bull. 56: 361 - 404.

Wilkin, P.; Thapyai, C. \& Chayamarit, K. 2007. Lectotypification of Dioscorea L. (Dioscoreaceae) names from Thailand. Kew Bull. 62: 251 - 258. 